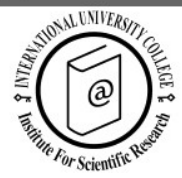

\title{
Geotourism potential of the islands of the western Mediterranean: Case study of Elba island
}

\author{
Laura Dryjańska ${ }^{1 *}$
}

Received: 12/02/2013 Accepted: 19/06/2013

\footnotetext{
1 "La Sapienza" University of Rome, Italy; mailing permanent address: Via Vezio Crisafulli 43, 00166 Rome, Italy; phone: +39 345808 7741; e-mail: laura.dryjanska@uniroma1.it

* Corresponding author
}

\begin{abstract}
The top-down structured paper consists of four parts. The first part discusses the Mediterranean Sea, focusing on the geological history of the islands of the western Mediterranean. The second part of the paper is dedicated to the Elba Island, including its geological structure, as well as describing the main minerals. The third part presents the original qualitative research carried out on Elba Island, aimed at assessing geotourism based on participant observation in four organized tours and semi-structured interviews. The findings reveal the participants' outlook on geotourism on Elba Island, leading to an identification of two different types of geotourists. As a theoretical implication, this distinction of types of geotourists can be applied to other geotourism destinations, while from the practical point of view it can guide marketing strategies related to the promotion of geotourism on the island. The conclusions focus on the discussion of the potential and current use of the Elba Island in the light of the findings of this case study, exploring links with other similar studies elsewhere, as well as future perspectives.
\end{abstract}

(C) 2014 International University College. All rights reserved

Keywords: geotourism; Elba; Mediterranean tectonics; geotourists

Citation: Dryjańska, L. (2014) Geotourism potential of the islands of the western Mediterranean: Case study of Elba island. European Journal of Tourism Research 7, pp. 127-139

\section{Introduction}

Geotourism has probably taken place ever since the beginning of the science of geology; however, it has been defined fairly recently, initially in the UK, passing into general academic usage in the early 1990's (Hose, 2008). Dowling and Newsome (2006), describe geotourism as interested after in "the natural resources of landscape, landforms, fossil beds, rocks and minerals, with an emphasis on appreciating the processes that are creating and created such features" (p. 3). Yet the authors themselves point out that one of the main concerns is the lack of a generally accepted definition (Dowling \& Newsome, 2006 , p. 248). In line with their understanding, further developed and objectified in the latest volume that they dedicated to geotourism and its resources throughout the world (Newsome \& Dowling, 2010), the foundation of this paper is 
the definition of geotourism after as "a form of natural area tourism that specifically focuses on landscape and geology" (p. 4). As such, geotourism includes natural and cultural tourist attractions that are specific to a geographic site (Buckley, 2003). For example, activities that occur in mines can be of interest to geotourism, contemporaneously falling under heritage tourism (Conlin \& Joliffe, 2011). Whether in a context of a mine or open space, exploring geographic locations is a learning experience for the tourists, which requires imagination and efficient communication in order to convey complex geological concepts (Pralong, 2006). While there is certainly a value in the discovery of relatively rarely visited sites thanks to their geomorphic riches, geotourism can also change the character of a highly seasonal traditional tourism to beach locations by offering attractions available year-round.

In fact, the Mediterranean Sea has always attracted tourists from all over the world, mainly because of its beaches, monuments of history and culture, and food and wine. Geotourism can be practiced almost anywhere, but the islands of the Western Mediterranean are a particularly interesting case, especially thanks to their geological history, which shows the complexity of the movement of the continental plates of Eurasia and Africa. Among many islands we can name one relatively little visited - Elba Island, which has been known for thousands of years, due to deposits of iron and the presence of many other minerals. Elba is an Italian island situated in the Tyrrhenian Sea, between Corsica and the Apennine peninsula, separated from the mainland by the Piombino Strait. The area of the island equals 224 square kilometers and it has approximately 32,000 inhabitants (Landini, 2008). Elba is the largest island of the Tuscan Archipelago and the third largest island in Italy. The relief is quite varied and often Elba is divided geographically into three parts: the mountainous western part with the Capanne Mountain (1018 m above sea level), also known as the roof of the Tuscan Archipelago; rather flat middle section with a width as small as $4 \mathrm{~km}$; and the oldest eastern part of the island with a hilly terrain and iron deposits.
The goal of this paper is to discuss the geotourism potential and its practical implications in case of Elba Island. Based on geological attractions already available, the author hopes to develop an initial situational analysis, including the geotourists' profile. Thus, the objectives of this paper consist of individuating the list of geological features of the island that appear attractive from the geotourism perspective, analyzing if and how local stakeholders are taking advantage of such attractions, and describing the types of tourists who practice geotourism on Elba Island.

\section{Western Mediterranean in a new time perspective}

In order to better understand geotourism, it is necessary to realize that it often requires a major shift in time perspective. While traditionally Mediterranean destinations appear as attractive to tourists thanks to their historical appeal, such as for example the ruins from the times of the Roman Empire, the time perspective of geotourism goes beyond the history of man and concerns the history of continents and seas. From this point of view, the challenge is to understand the complex Mediterranean geodynamics, marked by interaction between tectonics and igneous activity (Lustrino, Duggen \& Rosenberg, 2011). The geological history of the Mediterranean has been shaped by the complex interplay of the African and European plates combined with other several subduction zones (Carminati \& Doglioni, 2004), and therefore understanding its past appears as much more challenging than for example in case of Pacific subductions explained with simple magmatological models (Carminati, Lustrino \& Doglioni, 2012).

Concerning the geological history of the islands of the Western Mediterranean, it has been marked by two main stages of post-Cretaceous deformation (Smith et al, 2011): the collision between the Adria and Corsica-Sardinia microplates, followed by the extension that resulted in the opening of the Tyrrhenian basin (Keller \& Coward, 1996). A progressive eastwards migration took place during both stages (Elter et al, 1975; Pauselli et al, 2006). 


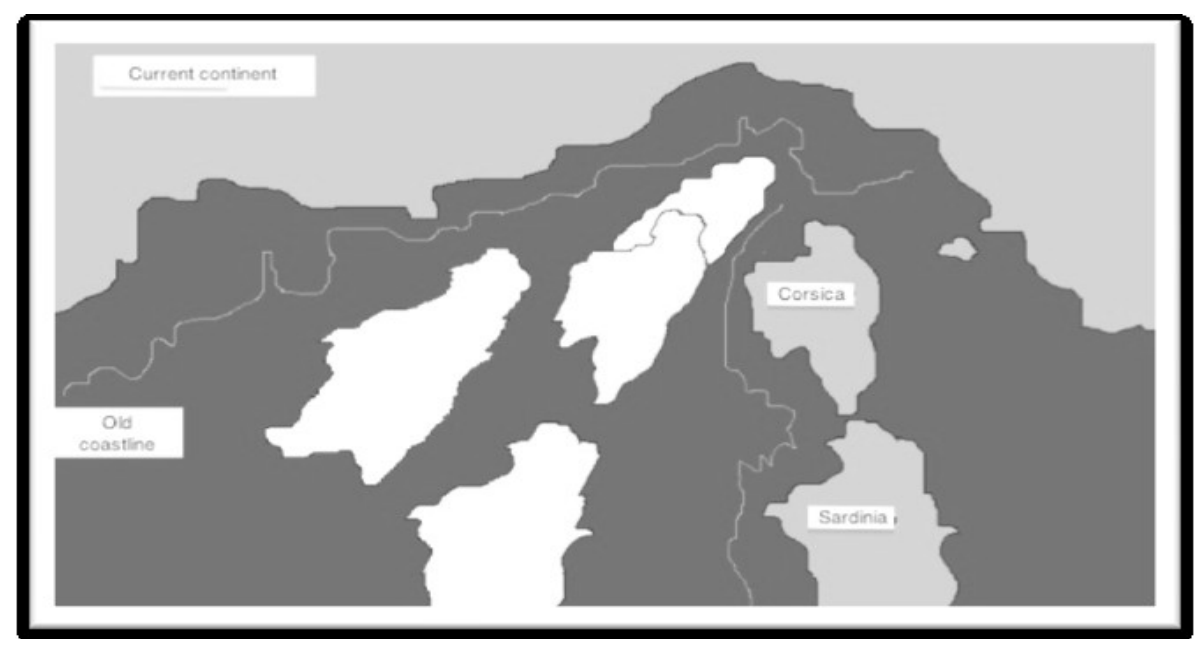

Figure 1. The motion of the Corsica-Sardinia block

(Designed by the author after Keller et al.,1994)

According to Colomo (2004), Corsica, Sardinia and Elba together formed a block, which was located near the present Mediterranean coast of France and Catalonia and drifted towards the present Italian mainland. A subduction of the Apulian crust under the block of Corsica, Sardinia and Elba took place after the collision leading to the mechanical thinning of the lithosphere beneath the orogenic belt (Keller et al., 1994). This process is simplified and illustrated in the Figure 1.

The complex geological history of the Western Mediterranean outlined above may be helpful to understand the particular case of Elba Island, its structure and numerous attractions it offers to different types of visitors interested in geotourism.

\section{Geotourism resources of Elba Island}

Traditionally, the geological structure of the central and eastern Elba is based on five tectonic complexes (Trevisan, 1950) that pertain to the Tuscan and Ligurian paleogeographic domains. These five complexes have been subsequently described as thrust sheets stacked towards the Northeast in the period from the Late Cretaceous to the Early Miocene (Keller \& Pialli, 1990). While analyzing the geological map of Elba by Meneghini (1885), it immediately strikes us that the island is divided into two parts: the younger and less diverse in terms of geology western part and the older and more differentiated eastern part.

The complex tectonic history of Elba Island resulted in its complex structure, which in turn contributed to the presence of numerous different minerals. In fact, for centuries Elba has been known as the mineralogical jewel of the Tuscan Archipelago. Among the minerals, which are typical for the Elba Island we can distinguish the following, highlighting come of the characteristics and history described in detail by Rinaldi (2002):

- Azurite - occurs mainly in The Cape Calamita Cave near the village of Grotta Rame.

- Cuprite - cuprite in Elba Island was identified as early as 1907 near the Grotta Rame; it often contains magnetite factions.

- Iron (Fe) - used since the late Neolithic men became aware of the presence of iron in some islands of the Tuscan Archipelago. Currently closed iron mines are located along the east coast and Cape Calamita. They constitute geotourism attractions, as the local authorities have permitted guided tours of some of them, such as the old Calamita Mine shown in Figure 2.

- Pyrite - together with quartz, pyrite used to create the nucleus of a number of mineralogical collections. Pyrites from Elba 


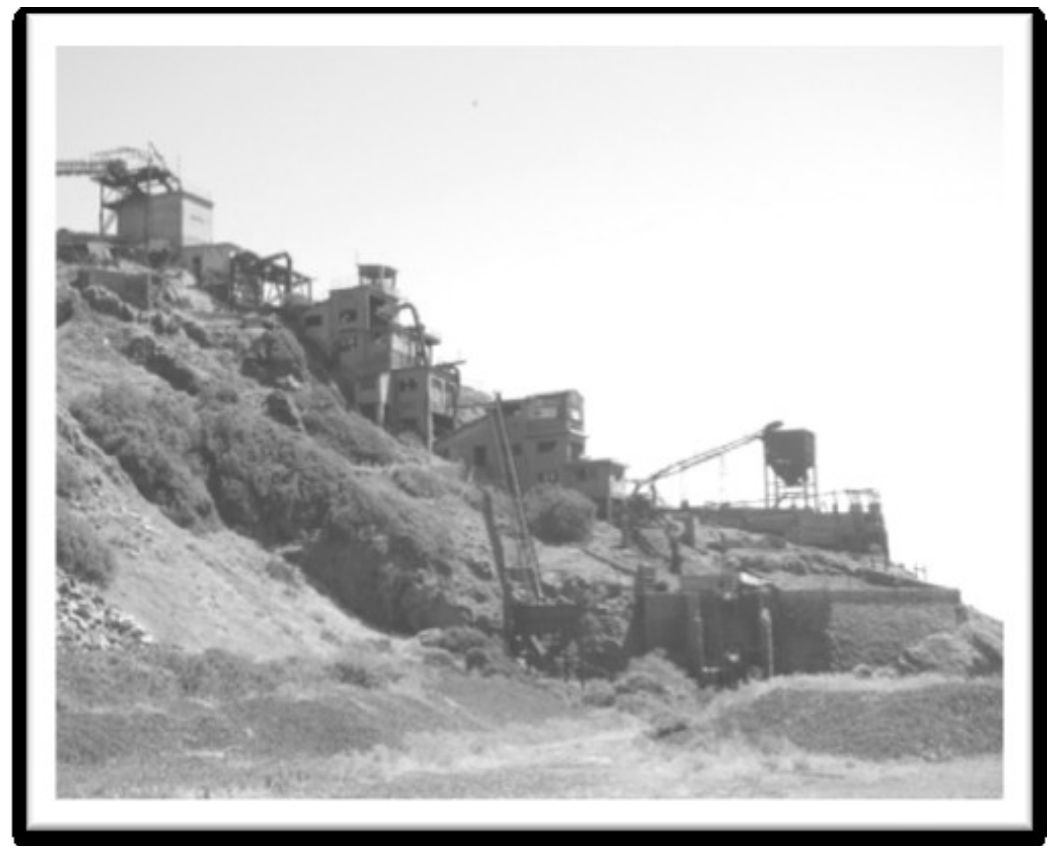

Figure 2. Old Calamita mine

have never been used on an industrial scale, but nicer mineralogical specimens adorn museums in many countries.

- Elbaite - the first new mineral found on Elba, a form of tourmaline. Apart from Elba Island, this mineral occurs in very few parts of the world. Elbaite has well formed crystals of a considerable size (up to $5 \mathrm{~cm}$ - specimen of Torre di Rio Marina).

- Quartz - this is a fairly common mineral that occurs in Elba Island. The most common variety of quartz is the green kind, particularly easy to find in the region of II Porticciolo. Specimens from there are up to a length of $6 \mathrm{~cm}$. Pink amethyst crystals with a maximum length of $5 \mathrm{~cm}$ and fluid inclusions have been found in Bacino, Vigneria and Falcacci, accompanied by hematite.

- Hematite - one of the most common iron minerals used to obtain the metal. Ever since the times of the Etruscans it has been one of the minerals mined on Elba in the largest quantity in order to obtain iron. In the museum in Rio Marina one can admire the impressive specimen with remarkable crystals, found near this village.
The minerals that can be found or/and bought on Elba are of considerable interest to geotourists. The scope of the above description was to move from the wide picture, the history and characteristics of the Mediterranean Sea, through the specific geological history of the islands of the Western Mediterranean to looking closely at Elba Island. A similar approach could be used for virtually any other geotourism destination in the world in order to assess its value (Wojtowicz, Strachowka \& Strzyz, 2011).

\section{Methodology of the case study}

The case study concerning geotourism currently practiced on Elba Island was carried out in 2009, during two trips that lasted approximately one week each (in the months of June and September). The methodology consisted of two complementary tools: ethnographic participant observation (DeWalt \& DeWalt, 2011; Bryman, 2012) and semistructured interviews (Crang, 2002; Diefenbach, 2009) with sixteen representatives of the main stakeholders involved in geotourism.

First, concerning the participant observation it has been narrowed down to four events offered to geotourists: two guided visits with 


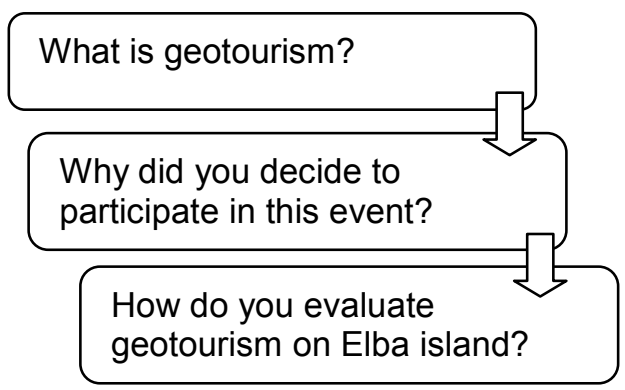

Figure 3. The main interview questions

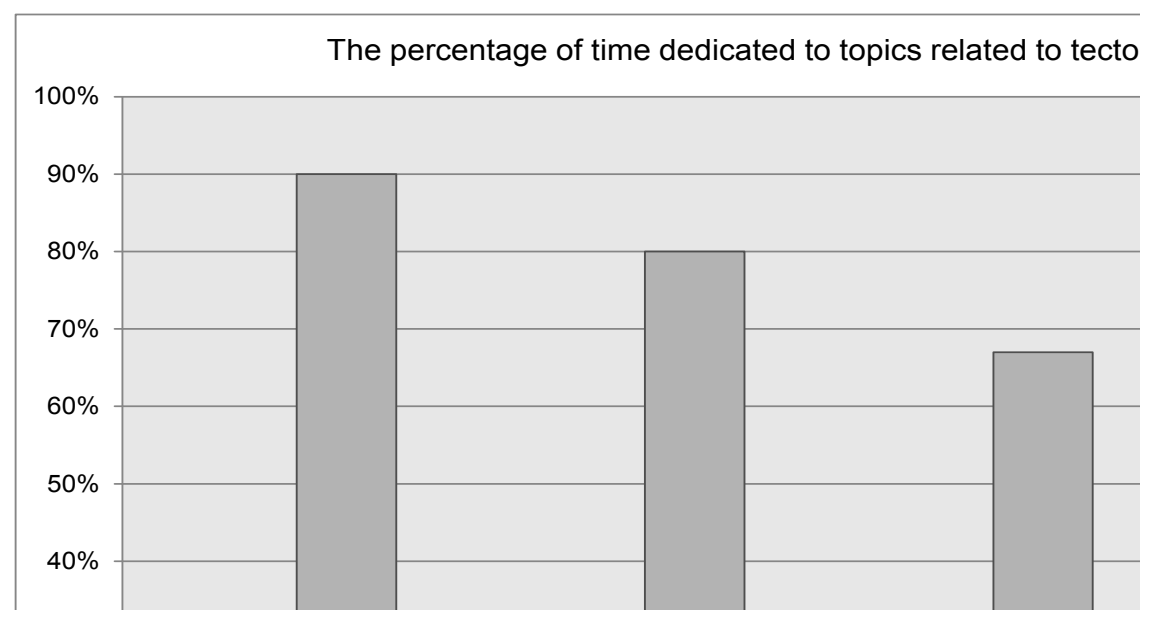

Figure 4. The percentage of time dedicated to topics that fall under the categories of tectonics and mineralogy during four tours

approximately twenty participants each to geological museums during two different seasons (Museo dei Minerali della Gente di Rio in June called "Tour 1" and Museo Archeologico Minerario in September called "Tour 2"), as well as two organized tours for approximately twelve participants each to the old mine of Capoliveri (called "Tour 3") and the artificial Little Mine of Porto Azzurro (called "Tour 4"). During the visits, the researcher took notes that assessed the demographic characteristics of the participants (age and gender) and wrote down their questions and time that the group dedicated to different topics/activities. There was no direct intervention in any way on the part of the observers who limited themselves to follow the group.

Second, once the guided visits were over, the researcher scheduled interviews with selected participants (eight persons), tour guides (four persons) and other local experts in geology and mineralogy (four persons) contacted using the snowball technique, thanks to the initial contacts with the tour organisers.

The interviews have been semi-structured in such a way that the three main questions have been asked (see Figure 3), but in some cases different additional questions occurred that ensured the natural flow of the conversation and allowed for the better understanding of the interviewee. The length of the interviews varied from forty minutes to an hour and the location depended on the person interviewed, in order for them to feel at ease. The researcher carried out the interview, while her assistant took notes.

The replies have also been timed by the assistant, and, subsequently categorized independently by the researcher and her 
assistant, in order to create a concise grid that contained the essence of the actual answers. In this way, the researcher could understand in depth the point of view of each participant (thanks to the possibility of asking additional questions), which is not possible when using a questionnaire.

\section{Presentation and discussion of the results}

The systematic observation of the proportion of time dedicated to different topics, both by the tour guide independently and by the participants' questions, during each of the four events assisted is presented in Figure 4. While many particular issues have been discussed, they could be fairly easily categorized as relating to either tectonics or mineralogy. As demonstrated in Figure 4 below, during all tours significantly more time was spent on topics related to minerals on Elba Island.

The prevalence of topics related to mineralogy is probably due to the fact that the museums visited were both mineralogical. Given the geological history of Elba Island, this is what draws geotourists who often hope to enrich their personal collections either by buying or by finding new minerals themselves. However, as an introduction in each case the tour guides do dedicate some time to the Mediterranean tectonics and geological history of Elba Island in particular. For this reason, topics related to tectonics are not completely absent during the tours. It seems that the visits to mines (where geomorphology of the island tends to be discussed during the bus ride) raise more awareness concerning tectonics and information about the landscape. This may be due to the interest in visiting and understanding the underground space, such as caves and mines that appears as one of the characteristics of geotourists in general (Garofano \& Govoni, 2012).

When asked the question "What is geotourism?" very few interviewees attempted to give a definition. Highlighting the practical aspects, they concentrated on the benefits of geotourism, often anticipating the next question that concerns the reasons to practice it. In general, the participants considered geotourism as a source of income, even if it was not a source of their personal profit. In fact, the majority of participants (44\%) centered their reply concerning geotourism on financial benefits that it brings to individuals and community, highlighting not only direct investment in geological tours, but also all the related expenses concerning transportation and infrastructure, such as the use of school minivans during the holidays. On the one hand, all tour guides have underlined the economic benefits, as stated by this interviewee:

To me, geotourism is a way to earn extra money as a guide. It is only worth it to take a group to the mine when I have at least six people. The municipality also has to make money on this business, so we have to pay for fees and permissions. But at least they use the school minivans in summer, so they [the minivans] don't just sit there idle like that. No, they bring money.

(Maletour guide in his thirties)

On the other hand, people who participate in tours are also aware of the fact that geotourism is a financial resource to the tour organizers, as well as the local economy, as explained by this interviewee:

My kid has fun and we oil the wheels of local economy [laughs]. Geotourism, as you call it, is a nice way to keep the folks busy with work. [...] We go to these mining towns that are not on the beach, so they don't get as many tourists, and we eat there, buy souvenirs, talk to folks, and spend money there, not only on tours but on all the rest too.

(Maleparticipant of a tour, in his fourties)

Another way to perceive geotourism is to see it as a hobby, a way to spend free time on an enjoyable activity, which was the second most frequent answer given by one fourth of all the interviewees, especially the participants of tours. The following answer is a good example of this outlook on geotourism:

I love geotourism! Other people practice sports or play instruments, and my hobby is geotourism. I had a great time on this trip; elbaite is just so pretty, don't you think? I take pleasure in seeing gorgeous minerals like that.

(Female participant of a tour, in her fifties) 
Two other ways of perceiving geotourism focus on a learning experience and an additional attraction. Approximately $19 \%$ of the interviewees, especially experts in geology and one of the participants in tours seem to perceive geotourism as a learning experience, a way to see in the real life some theoretical geological concepts, with an adequate explanation. They emphasized the educational value of geotourism, for example for their children, as something that could be helpful in school, or as a part of lifelong learning for older adults. Finally, two participants of tours classify geotourism as a specific form of tourism, an alternative to the beach tourism, gastronomic tourism, etc. These participants value variety when they travel and appreciate the wide range of attractions that Elba offers, including geotourism.

Most of the interviewees gave quite an exhaustive reply when asked what geotourism was; however, the term itself has not always been familiar at first, as demonstrated by this answer of an owner of a store with minerals:

I'm not exactly sure what people mean by geotourism. I guess it doesn't matter, we have been showing and selling minerals for generations here and now the fashion may be to call it geotourism, when people come from far away, even from abroad, like the Germans, to appreciate what we have here.
But they have done it for a long time, so geotourism is a new name for an old thing.

(Male, expert in mineralogy, in his sixties)

The answers to the second question concerning personal involvement in geotourism reflected the definitions of geotourism, giving additional insight into individual stories. Figure 5 below demonstrates how the reasons for participation were related to the function of each person.

The reasons to get involved in geotourism on Elba Island depended on the personal situation. The tour guides (who in some cases were also geologists) explained their activity mainly as a way to earn extra money, but also as an opportunity to teach some basic principles of geology to the general public. Similarly, experts who worked at the museums also considered their involvement in geotourism as an extra job, as well as a way to share their knowledge and to simply accompany tourists, not as a very active involvement, but rather as an additional source of information. On the other hand, from the point of view of many tourists their participation was a consequence of keeping company to their friends or loved ones in order to understand some more about their hobby, as the following interviewee:

I'm here only because of my boyfriend, he has just graduated in geology and it seems super hard, I mean all that he had to study...

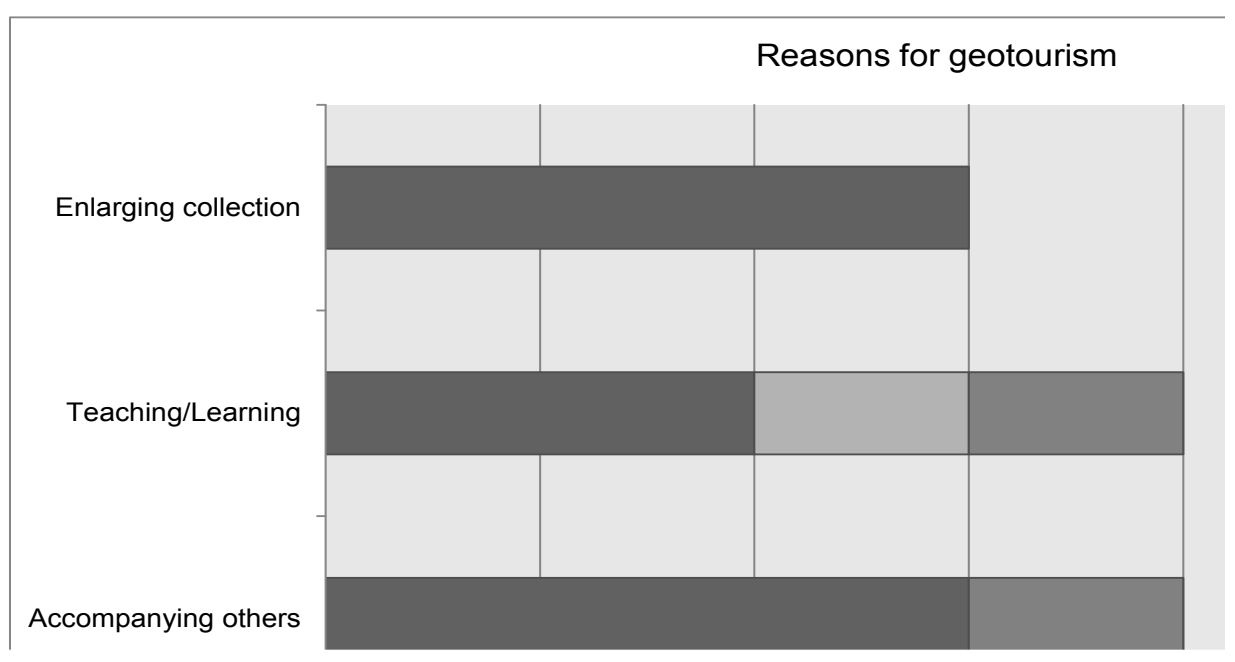

Figure 5. The reasons for personal involvement in geotourism 
So this trip is like a way to have an idea of his passion. I came because in this way we get to do this together. Sure, in general I prefer to tan or go shopping [...]. But this is interesting and my boyfriend looks very cute with the hammer [laughs], it's the first time I get to see kind of what he does.

(Female participant of a tour, in her twenties)

While $25 \%$ of tourists considered their involvement in the tour on Elba Island as a learning experience, while almost $30 \%$ of tourists emphasized the importance of enlarging their personal collection of minerals. For example, an eight-year-old participant demonstrated an impressive knowledge of various minerals and their characteristics both during the tour and while he was interviewed (in the presence of his parents and with their consent). In his own words:

You know, I have two rooms full of rocks. Geotourism is about collecting minerals, being able to recognize them and to find them. I also have some books that teach you how to recognize them, it's not always easy and sometimes they sell you fake ones, so you really have to know the minerals.

(Male child participant of the tour)

Reasons for geotourism differ based on the function of a person, as well as personal interests. On the whole, comparing the replies to the first two questions, there is an affinity with the perception of geotourism, except for the particular emphasis on collecting minerals.

Concerning the third question, the evaluation of geotourism on Elba Island, the interviewees shared their general impression and with auxiliary questions have been asked to explain positive and negative aspects (if any), as well as to rate it on a scale as demonstrated in Table 1 below.

For all interviewed participants, their geotourism experience on Elba Island has been a positive event, described with enthusiasm. The majority of the tourists rated geotourism on Elba Island as very good and all of them would be willing to repeat this type of experience in a different context. Only one participant rated her experience as fair, justifying her choice as follows:

My own poor health made it impossible for me to fully enjoy the tour. The problems with my knees made me stop and wait for everyone else when they went to the mine. Yes, I could sit in the shade but I got a bit bored then.

(Female participant of a tour, in her fourties)

The above statement can be interpreted as an invitation to organize some more geotourism events for persons with disabilities, in order to improve the overall quality of it on Elba Island. The tour guides have also been positive about geotourism that they have organized and they rated it as good and very good. Even though overall positive, the experts appeared less enthusiastic and during the conversation pointed out to many aspects that could be improved, especially when facing the legislative aspects, marketing and funding of geotourism projects. Some of the experts mentioned the concept of geoparks and how their development has helped to improve public understanding of geology and promote sustainable development through geotourism, in line with the general scientific approach to it (Farsani et al, 2011; Zouros, 2010).

Considering overall results of participant observation and interviews in the particular case of Elba Island, some conclusions about the tourists can be drawn, which may be applied to other visitors involved in geotourism in the islands of Western Mediterranean. In fact, based on the study presented above, two main types of geotourists can be identified: a student and a collector. On the one hand, a student finds especially attractive the global geological history of the Earth and of a single destination as a part of a big picture. He or she enjoys imagining and envisioning the past and has a special appreciation for geomorphologic characteristics of the territory. It is worth mentioning that a student does not have to be young, as the term is used in line with the concept of lifelong learning (Field, 2010). Probably, such approach of a student is in line with that person's cognitive style, way of processing information and being able to imagine space, movement and various 
Table 1. The overall evaluation of geotourism in Elba Island

\begin{tabular}{lccc}
\hline & Tourists & Tour guides & Experts \\
\hline Poor & 0 & 0 & 0 \\
Fair & 1 & 0 & 1 \\
Good & 2 & 2 & 2 \\
Very good & 5 & 2 & 1 \\
\hline
\end{tabular}
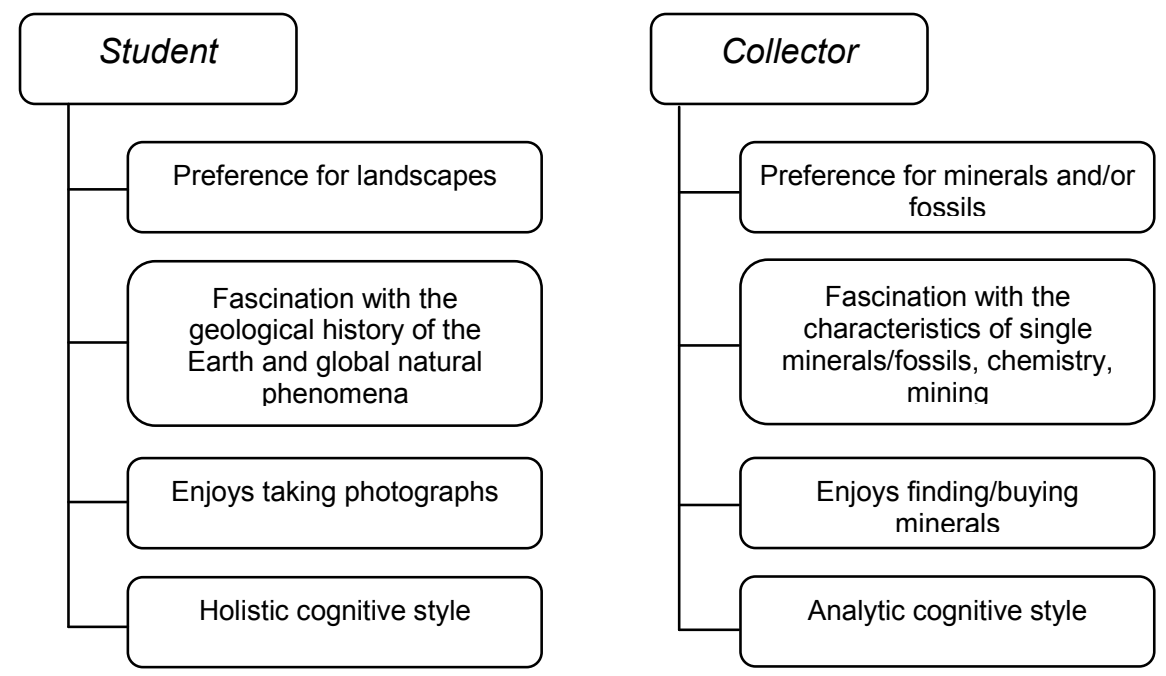

Figure 6. Types of geotourists

dimensions, time appearing as the dimension of key importance, and a general preference for abstract versus concrete (Harvey et al, 1961). On the other hand, a collector finds appealing minerals and/or fossils. This type of a geotourist is much more interested in the characteristics of certain minerals, how they originated, how they have been exploited throughout centuries. While a student probably appreciates more a land formation, a collector prefers a mining activity, a museum of minerals or a store that sell different minerals. The cognitive style of a collector focuses more on detail and concrete aspects (Harvey et al, 1961), such as being able to distinguish one mineral from another, to classify them and to possess them. Often geotourists create their own collections of minerals and/or fossils.

Some research in other geotourism destinations confirms that using a distinction between communication strategies that explore the spatial and temporal dimensions of the rocks on the one hand and of the landscape forms on the other can be particularly efficient in marketing (Pralong, 2006). The distinction of types of tourists characterizes geotourism that has been studied in a particular location. Of course the two types do not necessarily exclude each other, but usually there is a preference that a person can easily identify. Why is it useful? The geologists who work with groups on Elba Island discovered that by detecting the dominant preference of the group of tourists they can cater to their needs and thus give the tourists a more satisfactory experience. Based on the interviews with the geologists and observation of their interaction with the group, the author realized that such behavior often occurs in a natural way. The distinction offered is the attempt to name and classify what is actually happening during a geotourism tour on Elba Island. It is reasonable to assume that a similar phenomenon can be observed elsewhere, not only in geotourism, but also in different types of niche tourism as opposed to mass tourism (Novelli, 2004). Moreover, the types of geotourists described above reflect some of the 
Geotourism potential of the islands of the western Mediterranean: Case study of Elba island.

Table 2. Geotourism resources of Elba Island

\begin{tabular}{ll}
\hline \multicolumn{1}{c}{ Well-established resources } & \multicolumn{1}{c}{ Innovative ideas } \\
\hline Landscape tours & Visits to old mines \\
Mineralogical museum & Interactive artificial mines \\
Shops with minerals & Little train for children with explanations of landscape \\
Traditional jewelry stores with minerals & Personalized design jewelry stores \\
Specialized bookstores & Shops with geological equipment \\
\hline
\end{tabular}

Table 3. Profiles of geotourism markets and tourists

\begin{tabular}{|c|c|c|c|c|}
\hline Market Profile & Accidental & General & Interested & Scholarly \\
\hline Description of tourists & $\begin{array}{l}\text { No previous decision } \\
\text { to visit }\end{array}$ & $\begin{array}{l}\text { Planned trip or } \\
\text { group outing }\end{array}$ & $\begin{array}{l}\text { Specific interest in } \\
\text { the site }\end{array}$ & $\begin{array}{l}\text { Considerable } \\
\text { knowledge }\end{array}$ \\
\hline Preferred attractions & $\begin{array}{l}\text { Mineralogical stores } \\
\text { and jewelry shops }\end{array}$ & $\begin{array}{l}\text { Artificial } \\
\text { attractions also } \\
\text { for children, } \\
\text { man-made sites }\end{array}$ & Natural landscape & $\begin{array}{l}\text { Authentic old mines, } \\
\text { traditional museums }\end{array}$ \\
\hline Types of geotourists & $\begin{array}{l}\text { Predominantly } \\
\text { collectors }\end{array}$ & $\begin{array}{l}\text { Those who } \\
\text { accompany } \\
\text { students or } \\
\text { collectors }\end{array}$ & $\begin{array}{l}\text { Predominantly } \\
\text { students }\end{array}$ & $\begin{array}{l}\text { Either student or } \\
\text { collector }\end{array}$ \\
\hline
\end{tabular}

four major components of geodiversity (Thomas, 2012): mineralogical/petrographic diversity, paleontological diversity, structural and tectonic diversity, and geomorphologic diversity.

\section{Conclusion}

Geotourism in Europe is developing in a dynamic way, as exemplified by geotourism attractions on Elba Island. The number of people interested in geology, and in particular in mineralogy, is considerable and it is worthwhile to take advantage of the geotourism potential of the sites that have been around for many years as typical tourist destinations, thanks to an attractive position, climate, numerous beaches and interesting history. As pointed out by Gates (2006), geology has a strong impact on public recognition of scenic areas.

Elba Island contains very interesting geotourism attractions, as well as a geological past quite unique and worth seeing, which is the case of some other island destinations that have been studied from the point of view of their geosites (Paez et al, 2011). After consultations with geologists who work in the island, and especially after visiting it many times, the author realized that although the term "geotourism" is not very widely used by the inhabitants and tourists, geotourism is in fact widespread and practiced. Table 2 summarizes geotourism resources of the island, classified as either traditional or modern.

The main form of promotion of geological knowledge on Elba Island consists of mineralogical museums and stores, as well as organized tours to old mines. While museums have often been established many years ago, the idea of organizing events such as geotourism day trips for groups of up to twelve people with a guide (who is a geologist), has emerged fairly recently as an initiative of the municipalities. These types of trips take place only if there are a sufficient number of participants, and, usually happen during the holiday season. The municipality provides a minivan and entrance to the restricted area of an old mine, giving the opportunity to the participants to collect minerals, in consultation with the guide when it comes to the recognition of rocks. It is worth noting that without the consent of the local authorities this type of geotourism project would not be feasible. Interestingly, this case study is not a part of the general geopark movement that promotes geotourism (Dowling, 2008), but rather a result of observation of spontaneous efforts of the local scientific community, policy makers and store owners to cater to the needs of visitors interested in geology, whether the stress is on landscape or on mineralogy.

Although official mineralogical museums have existed on the island for many years, a new 
tendency is to offer a possibility of an active involvement, as in the case of individual search for minerals in a designated area. Moreover, specific educational attractions have been designed for children, such as a train ride with explanations of landscape and details of the work of miners. Through the dissemination of geotourism in Elba Island, we could observe a boom of trade in relation to minerals, jewelry and geological literature, and even hammers. In most small towns in the eastern part of the island, there are numerous "geotourism shops" and local people wholeheartedly support these type of initiatives, as they offer them income, jobs and skill development (Farsani et al, 2011). Geotourism provides an opportunity for small, ex-mining towns that are not located right by the sea and nevertheless manage to draw tourists thanks to the geological attractions, also during the seasons of Spring and Fall, when Elba Island is less visited than in Summer.

Elba is an island attractive from the point of view of geotourism, with its triple focus on geology, environmental education and fostering local community benefits (Newsome, Dowling \& Leung, 2012). Its advantages are well known, and appreciated, by visitors especially from Italy and Germany, as evidenced by the fact that most of the signs and signposts, as well as publications for tourists are available in these languages. While attitudes and behaviors of travelers can certainly give some insight into the dimensions of geotourism (Boley, Polovitz \& Bosak, 2011), looking at Elba Island as a tourism market offers additional insight to the types of geotourists discussed. While in general in tourism scholarly visitors tend to be the least numerous, this may not be the case in the specific setting of geotourism. Concerning the profiles of geotourism markets (Gorman, 2007), the corresponding types of geotourists are summed up in Table 3.

The existing typologies of markets (Gorman, 2007) take into account different aspects of geotourism than the proposed distinction between students and collectors. In fact, while Gorman's profiles concentrate on the time spent and market size, the types of geotourists do not repeat this classification but highlight a different dimension of the phenomenon, since for example both students and collectors may be very knowledgeable before the visit. Tourism process occurs within all market profiles, but the challenge for geotourism is to transform accidental and general participation into more focused and knowledgeable. The suggested way of achieving this result consists of improving the quality and educational aspects of man-made attractions, channelling the resources to both traditional and innovative activities. Experts in multiple disciplines need to work together on aspects related to marketing, transportation, and geology knowledge dissemination.

The challenge of studying a case in the multidisciplinary framework of geotourism has been to present sound background from the point of view of both geology and tourism, in the particular context of Elba Island. The author hopes that this study has succeeded in highlighting the complex geological riches of the destination, as well as how they are conveyed to tourists who in turn can be classified based on their geotourism preferences.

The limitation of this study may be the fairly low number of participants and events that has been taken into account. Without doubt, having some official statistics of all geotourism activities on Elba Island would give a more complete picture. However, the qualitative and more anthropological nature of this case study has the value of analysing in depth each of the four tours and dedicating enough time to each of the persons interviewed. In fact, Guest, Bunce and Johnson (2006) found with their study, which involved 60 interviews that theme saturation was achieved after 12 interviews.

An interesting research question that could guide future studies is related to the fact that while Elba Island offers minerals to collect, other geotourism destinations are rich in fossils. One may wonder if and how being interested in fossils versus minerals changes the behaviour of a geotourist. The typology of geotourists may also be influenced by the physical conditions, and a study of geomorphologic hazards on Elba Island could be a promising development. Such studies 
have been carried out in other parts of Italy (Brandolini \& Pelfini, 2010).

Certainly, more work is necessary in this area, preferably taking into account the aspect of conservation of geosites, since site management is a vital component of geotourism (Newsome, Dowling \& Leung, 2012). Nevertheless, this study shades some light on geotourism potential of Elba Island, classifying the resources, as well as types of tourists who currently explore the geology of the island in various ways.

\section{References}

Boley, B.B., Polovitz Nickerson, N. \& Bosak K. (2011). Measuring geotourism: developing and testing the geotraveler tendency scale (GTS). Journal of Travel Research, 50, 567-578.

Brandolini, P. \& Pelfini, M. (2010). Mapping geomorphologic hazards in relation to geotourism and hiking trails. In G. Regolini-Bissig and E. Reynard (Eds), Mapping Geoheritage, Lausanne: Geovisions 35, 31-45.

Bryman, A. (2012). Ethnography and participant observation. In A. Bryman, Social Research Methods (pp. 430467). New York, USA: Oxford University Press.

Buckley, R. (2003). Environmental Inputs and Outputs in Ecotourism: Geotourism with a Positive Triple Bottom Line? Journal of Ecotourism, 2(1), 76-82.

Colomo, S. (2004). Geografia e ambienti naturali della Sardegna. Nuoro, Italy: Editrice Archivio Fotografico Sardo.

Conlin, M.V. \& Joliffe, L. (2011). Mining Heritage and Tourism: A Global Synthesis. New York, USA: Routledge.

Carminati, E. \& Doglioni, C. (2004). Mediterranean tectonics. EUROPE: Mediterranean tectonics and neotectonics, 135, 1-12.

Carminati, E., Lustrino M. \& Doglioni, C. (2012). Geodynamic evolution of the central and western Mediterranean: Tectonics vs. igneous petrologyconstraints. Tectonophysics, 579, 173-192.
Crang, M. (2002). Qualitative methods: the new orthodoxy? Progress in Human Geography, 26(5), 647-655.

DeWalt, K.M. \& DeWalt, B.R. (2011). Participant Observation: A Guide for Fieldworkers. Plymouth, UK: AltaMira Press.

Diefenbach, T. (2009). Are case studies more than sophisticated storytelling?: Methodological problems of qualitative empirical research mainly based on semi-structured interviews. Quality \& Quantity, 43(6), 875-894.

Dowling, R. (2008). The emergence of geotourism and geoparks. Journal of Tourism, 9(2), 227-236.

Dowling, R. \& Newsome, D. (Eds.) (2006). Geotourism. Amsterdam: Elsevier, Ltd.

Elter, P., Giglia, G., Tongiorgi, M. \& Trevisan, L. (1975). Tensional and compressional areas in recent (Tortonian to present) evolution of the northern Apennines. Bollettino di Geofisica Teorica e Applicata, 17, 3-18.

Farsani, N. T., Coehlo, C., \& Costa, C. (2011). Geotourism and geoparks as novel strategies for socio-economic development in rural areas. International Journal of Tourism Research, 13(1), 68-91.

Field, J. (2010). Lifelong Learning. In P. Peterson, E. Baker \& B. McGaw, International Encyclopedia of Education (pp. 89-95). Oxford, UK: Elsevier.

Garofano, M. \& Govoni, D. (2012). Underground Geotourism: a Historic and Economic Overview of Show Caves and Show Mines in Italy. Geoheritage, 4 (1-2), 79-92.

Gates, A.E. (2006). Geotourism: A Perspective from the USA. In R. Dowling and D. Newsome (Eds), Geotourism. Amsterdam: Elsevier, Ltd.

Gorman, C.E. (2007). Landscape and geotourism: Market typologies and visitor needs. European Tourism and Environment Conference: Promotion and Protection, Achieving the Balance. October, Dublin, Ireland.

Guest, G., Bunce, A. \& Johnson, L. (2006). How many interviews are enough? An experiment with data saturation and variability. Field Methods, 18(1), 59-82. 
Harvey, O.J., Hunt, D.E. \& Schroder, H.M. (1961). Conceptual systems and personality organization. New York: Wiley.

Hose, T.A. (2008). Towards a history of geotourism: definitions, antecedents and the future. The History of Geoconservation, 300, 37-60.

Keller, J.V.A. \& Coward, M. P. (1996). The structure and evolution of the Northern Tyrrhenian Sea. Geological Magazine, 133, 1-16.

Keller, J.V.A., Minelli, G. \& Pialli, G. (1994). Anatomy of late orogenic extension: the Northern Apennines case. Tectonophysics, 238, 275-294.

Keller, J.V.A. \& Pialli, G. (1990). Tectonics of the Island of Elba: a reappraisal. Bollettino della Societa Geologica Italiana, 109, 413-425.

Landini, P. (2008). Atlante geografico. Rome, Italy: Istituto dell'Enciclopedia Italiana Giovanni Treccani.

Lustrino, M., Duggen, S., Rosenberg, C., (2011). The Central-Western Mediterranean: anomalous igneous activity in an anomalous collisional tectonic setting. Earth-Science Reviews, 104, 1-40.

Meneghini, G. (1885). Geological map of Elba. Rome, Italy: Comitato Geologico.

Newsome, D. \& Dowling, R. (Eds) (2010). Geotourism: the tourism of geology and landscape. London, UK: Goodfellow Publishers Ltd.

Newsome, D., Dowling, R. \& Leung, Y. (2012). The nature and management of geotourism: A case study of two established iconic geotourism destinations. Tourism Management Perspectives, 2-3, 19-27.

Novelli, M. (Ed.) (2004). Niche tourism: Contemporary issues, trends and cases. Oxford, UK: Elsevier.

Paez, J.D., Ramirez, R.B., Cardenas, E.G., Martin, C.G. \& Lahoz, E.E. (2011). Geomorphosites and geotourism in volcanic landscape: The example of La
Corona del Lajial Cinder Cone (El Hierro, Canary Islands, Spain). GeoJournal of Tourism and Geosites, 2(8), 185-197.

Pauselli, C., Barchi, M. R., Federico, C., Magnani, M. B. \& Minelli, G. (2006). The crustal structure of the Northern Apennines (central Italy): an insight by the CROP03 seismic line. American Journal of Science, 306, 428-450.

Pralong, J-P. (2006). Geotourism: A new Form of Tourism utilising natural Landscapes and based on Imagination and Emotion. Tourism Review, 61(3), 2025.

Rinaldi, G. (2002). Mineralien - Gesteine und Erzlagerstatten der Insel Elba. Porto Ferraio, Italy: Edizioni Archipelagos.

Smith, S.A.F., Holdsworth, R.E., Collettini, C. \& Pearce, M.A. (2011). The microstructural character and mechanical signifiance of fault rocks associated with a continental low-angle normal fault: the Zuccale Fault, Elba Island, Italy. The Geological Society of London Special Publications, 359, 97113.

Thomas, M.F. (2012). A geomorphological approach to geodiversity - its applications to geoconservation and geotourism. Quaestiones Geographicae, 31(1), 81-89.

Trevisan, L. (1950). L'Elba orientale e la sua tettonica di scivolamento per gravita. Memorie dell'lstituto Geologico dell'Universita di Padova, 16, 1-30.

Wojtowicz, B., Strachowka, R., \& Strzyz, M. (2011). The perspectives of the development of tourism in the areas of geoparks in Poland. Procedia Social and Behavioral Sciences, 19, 150-157.

Zouros, N. (2010). Geodiversity and sustainable development: Geoparks a new challenge for research and education in earth sciences. Bullettin of the Geological Society of Greece, 1(168), 159-168. 